\title{
Eucalyptus urocam plant tolerance to salinity in response to silicon-based fertilization
}

\section{Tolerância de plantas de Eucalyptus urocam a salinidade em resposta a adubação silicatada}

Fabio Santos Matos

Universidade Estadual de Goiás

E-mail: fabio.agronomia@hotmail.com

OrclD: https://orcid.org/0000-0002-7666-006X

Liana Veronica Rossato

Universidade Estadual de Goiás

E-mail: liana.rossato@gmail.com

OrcID: https://orcid.org/0000-0002-0592-9682

Camila Lariane Amaro

Universidade Estadual de Goiás

E-mail: camila.lariane@gmail.com

OrcID: https://orcid.org/0000-0003-4013-1673

Frederico da Costa Mendes Silva

Universidade Estadual de Goiás

E-mail: freddie_0l@hotmail.com

OrclD: https://orcid.org/ 0000-0002-8466-4378

Gustavo Brunetto

Universidade Federal de Santa Maria

E-mail: brunetto.gustavo@gmail.com

OrcID: https://orcid.org/0000-0002-7260-7907

Carina Marchezan

Universidade Federal de Santa Maria E-mail: marchezancarina@yahoo.com.br

OrcID: https://orcid.org/0000-0001-6848-5188

Flávia Brito Hanzel

Universidade Federal de Santa Maria

E-mail: fsm.agronomia@hotmail.com

OrcID: https://orcid.org/0000-0003-3064-2728

\begin{abstract}
The environmental barriers to the expansion of the planted area increase the need to develop cultivation technologies in unsuitable regions with low quality saline water. The objective of the present study was to identify the effects of silicon-based fertilization on Eucalyptus plant tolerance to salinity. A completely randomized block design was used in a $2 \times 2$ factorial arrangement with two Si levels, 0 and $1 \mathrm{~g} \mathrm{~L}^{-1}$, in four leaf applications at 157, 164, 171 and 178 days after emergence (DAE) at a volume of $30 \mathrm{ml} /$ plant/ application and irrigated with water at two levels of electrical conductivity equal, 0 and $2.5 \mathrm{dS} \mathrm{m}^{-1}$ from 150 to $181 \mathrm{DAE}$ and six replications. The silicon-based fertilization minimized sodium absorption in Eucalyptus urocam plants irrigated with saline water but did not influence the entrance of chlorine in the plant. The vigorous vegetative growth, absence of nutritional deficiency and imbalance in potassium absorption indicated median tolerance of Eucalyptus urocamplants to salinity with $2.5 \mathrm{dS} \mathrm{m} \mathrm{m}^{-1}$ water electrical conductivity.
\end{abstract}


Keywords: Electrical conductivity, Forestry, Silicon.

Resumo: As barreiras ambientais para expansão da área plantada incrementam a necessidade de desenvolvimento de tecnologias de cultivo em regiões inaptas com água salina de baixa qualidade. O presente trabalho teve como objetivo identificar os efeitos da adubação silicatada na tolerância de plantas de eucalipto a salinidade. $O$ experimento seguiu o delineamento inteiramente casualizado em arranjo fatorial $2 \times 2$ com dois níveis de Si, 0 e $1 \mathrm{~g} \mathrm{~L}^{-1}$, em quatro aplicações foliares aos 157, 164, 171 e 178 dias após a emergência (DAE) em volume de $30 \mathrm{ml} /$ planta/aplicação e irrigação com água em dois níveis de condutividade elétrica iguais a: 0 e 2,5 dS m m$^{-1}$ dos 150 aos 181 DAE e seis repetições. A adubação silicatada minimizou a absorção de sódio em plantas de Eucalyptusurocam irrigadas com água salina, mas não influenciou a entrada de cloro na planta. O vigoroso crescimento vegetativo, ausência de deficiência nutricional e desbalanço na absorção de potássio é indicativo de mediana tolerância de plantas de Eucalyptusurocama salinidade com água de condutividade elétrica igual a $2,5 \mathrm{dS} \mathrm{m}^{-1}$.

Palavras chave: Condutividade elétrica, Silvicultura, Silício.

Data de recebimento: 01/04/2019

Data de aprovação: 19/12/2019 DOI: https://doi.org/10.30612/agrarian.v13i50.9638

\section{Introduction}

Growing demand for wood for civil and rural construction, furniture, packaging, playgrounds and artefacts has driven the Brazilian forestry sector to constant expansion. This sector accounts for $91 \%$ of all the wood produced for industrial purposes, $1.2 \%$ of all the wood produced of all the wealth generated in the country and $6 \%$ of the industrial GDP (Instituto Brasileiro de Geografia e Estatística [IBGE], 2017; Industria Brasileira de Árvores [IBÁ], 2017).

Brazil has about 7.8 million ha of planted forest, and eucalyptus represents 5.6 million ha. It is the fourth world producer of cellulose and the biggest of species of the genus Eucalyptus, followed by India and China (Dasgupta, Dharanishanthi, Agarwal \& Krutovsky, 2015; Du, et al., 2015; Amaro et al., 2017). The growth of the area planted with eucalyptus increases $2.8 \%$ a year and the main Brazilian producing states are Minas Gerais (24\%), São Paulo (17\%) and Mato Grosso do Sul (15\%). Together these three states account for approximately $56 \%$ of all the Eucalyptus plantations in Brazil (IBÁ, 2017).

The genus Eucalyptus found ideal conditions for development in Brazil. Productivity on Brazilian land is bigger than in Australia, country of origin of the species (Amaro et al., 2017). Brazil has excellent potential for planted forest exploitation in practically all the national territory, due to the diversity of edaphoclimatic conditions (Souza, Freitas, Lopes, Rosa, \& Matos, 2015). Starting in the second half of 2009 the areas planted with Eucalyptus spp. in Brazil increased significantly because of the up turnin sales exports, international price recovery and to the government initiative in waiving IPI on the productive chain of panels, furniture and industrialized wood (Martins, Pereira \& Lopes, 2013).

Brazil has high productive and competitive potential to produce eucalyptus consistently and sustainably, but research should be developed to generate technologies that increase these forest activities, to supply other segments of the economy and the external market (Schweitzer, 2016). Expansion of the planted area will certainly coincide with the development of cropping technologies for unsuitable regions with poor quality, saline water. Brazil has potential and perspective to double the irrigated area by 2026 (Associação do Irrigantes do Estado de Goiás [IRRIGO], 2017). Irrigation with saline water is a reality in semiarid regions where quality water for agriculture is not available (Lopes, Lima \& Klar, 2012). Salinity causes fall in crop yield due to osmotic, toxic and/or nutritional effects (Souza et al., 2015). According to Shannon, Crieve e Francois (1994), water electrical conductivity equal or bigger than $4 \mathrm{dS} \mathrm{m}^{-1}$ drastically reduces plant growth, whereas electrical conductivity less than $4 \mathrm{dS} \mathrm{m}^{-1}$ may not cause significant negative effects.

Adopting new management practices may be an important alternative in implementing and conducting forests in areas previously considered unsuitable. Mineral nutrition with silicon ( $\mathrm{Si}$ ) has been one of the factors responsible for satisfactory crop production and abiotic stress conditions. The use of silicon ( $\mathrm{Si}$ ) is a viable alternative beneficial to plants, and the main crop responses are pest and disease resistance, tolerance to heavy metal toxicity, salinity and water stress and above all increase in growth (Marafon \& Endres, 2013). Studies 
using Si sources resulted in positive growth increases in Zea mays and Moringa oleífera and in fiber quality in Gossypium hirsutum L. (Lima, Castro, Vidal, Enéas-Filho, 2011; Hussein \& Abou-Baker, 2014; Gama et al., 2016).

The element Si has a key role in plant - environment relationships and is considered a beneficial and anti-stress element, supplying some crops with better conditions to support edaphoclimatic and biological adversities, resulting an increase in the production quality, due to a series of actions in the plant metabolism that can absorb and accumulate in the plant tissues (Demattê, Pagiaro, Beltrame \& Ribeiro, 2011).

Anthropological actions on water resources and the growing expansion of the forest sector mean that the use of inferior quality water, usually saline, has become a reality. Numerous studies have shown that silicon is efficacious in improving resistance to biotic and abiotic stresses in various crops, by mechanisms of reducting the respiration rate and maintaining the leaf content (Yu et al., 2016). The objective of the present study was to identify the effects of silicon-based fertilization on eucalyptus plant tolerance to salinity.

\section{Material and Methods}

\section{Experimental Design}

The experiment was carried out in a greenhouse with a transparent plastic cover and sides coverd with

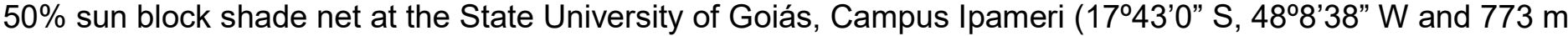
altitude), Ipameri, Goiás, Brazil. The region has a tropical climate with a dry winter and wet summer (Aw), according to the Köppen classification. There are two well-defined seasons: the wet season, from October to March and the dry season from April to September.

The experiment was set up using 150-day-old Eucalyptus urocam plants acquired from a specific nursery for sapling production at 100 days and planted in $10 \mathrm{~L}$ pots with substrate consisting of Oxisol (Santos et al., 2013), sand and manure at the proportion of 3: 1: 0.5 , respectively. Chemical analysis of the mixture showed the following values: $\mathrm{pH}\left(\mathrm{CaCl}_{2}\right) 6.5$ (ratio of $1: 1 \mathrm{v} / \mathrm{v}$ ); $21 \mathrm{~g} \mathrm{dm}^{-3}$ organic matter (Empresa Brasileira de Pesquisa Agropecuária [EMBRAPA],1997); $22.5 \mathrm{mg} \mathrm{dm}^{-3} \mathrm{P}$ and $0.55 \mathrm{cmol}_{\mathrm{c}} \mathrm{dm}^{-3} \mathrm{~K}$ (extracted by Mehlich-1) and $P$ determined by Murphy e Riley (1962); $2.4 \mathrm{cmol}_{\mathrm{c}} \mathrm{dm}^{-3} \mathrm{H}+\mathrm{Al} ; 1.8 \mathrm{cmol}_{\mathrm{c}} \mathrm{dm}^{-3} \mathrm{Ca}, 0.8 \mathrm{cmol}_{\mathrm{c}} \mathrm{dm}^{-3} \mathrm{Mg}, 9.7 \mathrm{mg}$ $\mathrm{dm}^{-3} \mathrm{Zn}$ (extracted by $\mathrm{KCl} 1.0 \mathrm{~mol} \mathrm{~L}^{-1}$ ); $5.32 \mathrm{cmol}_{\mathrm{c}} \mathrm{dm}^{-3} \mathrm{CTC}$ and $59.62 \%$ saturation by bases, calculated according EMBRAPA (1997). After analysis, it was decided not to lime or fertilize due to the high values of calcium and magnesium, base saturation and organic matter (Ribeiro, Guimarães \& Alvarez, 1999).

A complete randomized block design was used in a $2 \times 2$ factorial design with two Si levels, 0 and $1 \mathrm{~g}$ $\mathrm{L}^{-1}$, in four leaf applications at 157, 164, 171 and 178 days after emergence (DAE) at a volume of 30 $\mathrm{ml} /$ plant/application and irrigation with water at two electrical conductivity levels, 0 and $2.5 \mathrm{dS} \mathrm{m}^{-1}$, from 150 to $181 \mathrm{DAE}$ and six replications. The volume of irrigation to be applied was determined based on the difference in weight of the pots following recommendations by Dos Anjos et al. (2017). Maximum uniformity was attempted during the Si application, by spraying the leaf area, preventing run-off and any product loss. The solutions were prepared by diluting $\mathrm{Si}$ derived from marine algae fossilized rocks, consisting mainly of $\mathrm{SiO}_{2}($ Protect Bugram RSO 380 with $94.6 \% \mathrm{Si}$ ) in de-ionized water. Later the following variables were assessed: plant height, stem diameter, number of leaves, leaf area, relative water content, chlorophyll $a+b$, carotenoids, specifically area, biomass, root mass ratio, root length, transpiration and leaf percentage of macro and micronutrients.

\section{Physiological and nutritional variables}

Plant height and stem diameter were measured using a graded ruler and digital pachymeter, respectively. The number of leaves was measured by counting all the leaves on each plant. To determine the chlorophyll and total carotenoid concentration, leaf disks were removed from the known area and placed in jars containing dimethyl sulfoxide (DMSO). Later extraction was carried out in a water bath at $65^{\circ} \mathrm{C}$ for one hour. Aliquots were removed for spectrophotometric reading at 480,646 and $665 \mathrm{~nm}$. The chlorophyll a $(\mathrm{Cl} a)$ and chlorophyll $\mathrm{b}(\mathrm{Cl} b)$ contents were determined following the equation proposed by Wellburn (1994).

The leaves and the roots of each plant were placed individually in paper bags and dried in a chamber at $65^{\circ} \mathrm{C}$ until constant mass and then the dry matter was determined using digital scales. The leaves and roots were ground, prepared and subjected to nitrogen perchlorate digestion and $\mathrm{Zn}, \mathrm{Fe}, \mathrm{K}, \mathrm{Mg}$ and $\mathrm{Ca}$ were determined in the extract by atomic absorption spectrophotometry, P was determined by colorimetry (Tedesco, 
Gianello, Bissani, Bohnen \& Volkweiss, 1995). For the $\mathrm{Cl}$ and Na concentration, $1 \mathrm{~g}$ dry plant material was digested in ultra-pure water in a water bath at $80^{\circ} \mathrm{C}$ for 15 minutes. The samples were filtered,and the nutrient concentration was estimated by an inductively coupled plasma - optical emission spectrophotometer.

The total daily transpiration of the plant was determined by the difference in the pot mass. The set of pots with plants was placed inside individual plastic bags and closed with rubber around the plant stem, leaving the canopy exposed (leaves and stem). The pots were then weighed at 12:00 o'clock (mass 01) and again 24 hours afterwards (mass 02). The total transpiration was estimated based on the difference between mass 01 and mass 02 (Dos Anjos et al., 2017).

To obtain the relative water content, ten $12 \mathrm{~mm}$ leaf discs were removed, weighed and placed for four hours to saturate in petri dishes containing distilled water. The discs were again weighed and placed a dry at $70^{\circ} \mathrm{C}$ for 72 hours, and afterwards the dry matter weight was obtained.

\section{Statistical Procedure}

The experiment was set up in a completely randomized design in a $2 \times 2$ factorial arrangement with two Si levels, 0 and $1 \mathrm{~g} \mathrm{~L}^{-1}$ and two salinity levels, 0 and $2.5 \mathrm{dS} \mathrm{m}^{-1}$ and six replications. The data was submitted to analysis of variance and the Newman Keuls test to compare the means. Multivariate analysis was carried out by multiple regression using the forward stepwise model (Sokal \& Rolf, 1995). The R core team (R) (, 2018 software was used to carry out these analyses.

\section{Results and Discussion}

The salinity of the irrigation water and silicon-based fertilization did not interfere in the stem diameter, chlorophyll leaf concentrations and total carotenoids, and indicated absence of toxic effects from salinity at a biochemical level. Table 1 shows analysis of variance for plant height, biomass, root length, leaf area, transpiration and relative water content. Si interfered a little in vegetative growth of Eucalyptus urocam plants irrigated with saline water. Plant height, biomass, transpiration and relative water content were $10 \%, 15 \%, 26 \%$ and $12 \%$ lower in plants irrigated with saline water compared to those irrigated with non-saline water. Increase in electrical conductivity in the irrigation water significantly affected vegetative growth in eucalyptus plants. The similarity in the area, stem diameter, root length, ratios of root, stem and leaf mass among plants irrigated with saline solution and potable water was indicative of some degree of salinity tolerance intrinsic to the species. The results corroborated those found by Lopes et al. (2012) and Souza et al. (2015) who identified vigorous vegetative growth in eucalyptus plants irrigated with saline water.

The reduced osmotic potential of the soil solution may have hindered water absorption and consequently the Eucalyptus urocam plants decreased stomata opening to prevent tissue dehydration. The lower electrical conductivity limited $\mathrm{CO}_{2}$ inflow, photosynthesis and biomass accumulation. Stomata control by tree plants to minimize water loss underwater shortage or salinity has been reported by several authors (Duarte, Rocha, De Lima, Matos \& Rodrigues, 2016; Freitas et al., 2017; Matos et al., 2016).

Table1. Analysis of variance and means test for plant height, biomass, root length (RL), leaf area (LA), total transpiration (E) and relative water content (RWC), in Eucalyptus urocam plants fertilized with silicon(Si)and irrigated with saline water

\begin{tabular}{|c|c|c|c|c|c|c|c|}
\hline \multirow{3}{*}{ Source of Variation } & \multirow{3}{*}{ GL } & \multicolumn{6}{|c|}{ Mean Squares } \\
\hline & & Height & Biomass & $\mathbf{R L}$ & LA & $E$ & RWC \\
\hline & & $\mathrm{cm}$ & $g$ & $\mathrm{~cm}$ & $\mathrm{~cm}^{2}$ & $m$ dia $^{-1}$ & $\%$ \\
\hline $\mathrm{Si}$ & 1 & $0.06^{\mathrm{ns}}$ & $65.34^{\text {ns }}$ & $0.021^{\mathrm{ns}}$ & $100.08^{\text {ns }}$ & $6337.5^{\mathrm{ns}}$ & $255.06^{\text {ns }}$ \\
\hline $\mathrm{NaCl}$ & 1 & $0.07^{*}$ & $2359.77^{*}$ & $0.015^{\mathrm{ns}}$ & $57.25^{\mathrm{ns}}$ & $3 \times 10^{5 * *}$ & $601.60^{* *}$ \\
\hline $\mathrm{Si}^{*} \mathrm{NaCl}$ & 1 & $0.01^{\mathrm{ns}}$ & $12.41^{\mathrm{ns}}$ & $0.004^{\mathrm{ns}}$ & $227.98^{\text {ns }}$ & $79350^{\text {ns }}$ & $66.60^{\text {ns }}$ \\
\hline Resdue & 15 & 0.12 & 430.73 & 0.066 & 121.27 & 1515.42 & 36.20 \\
\hline CV (\%) & & 9.82 & 17.65 & 19.89 & 18.90 & 5.30 & 5.08 \\
\hline
\end{tabular}




\begin{tabular}{ccccccc} 
With $\mathrm{Si}$ & $1.10 \mathrm{a}$ & $119.2 \mathrm{a}$ & $1.33 \mathrm{a}$ & $56.23 \mathrm{a}$ & $75.13 \mathrm{a}$ & $83.37 \mathrm{a}$ \\
Without $\mathrm{Si}$ & $1.20 \mathrm{a}$ & $115.9 \mathrm{a}$ & $1.27 \mathrm{a}$ & $60.32 \mathrm{a}$ & $71.88 \mathrm{a}$ & $87.89 \mathrm{a}$ \\
\hline Treatment 2 & \multicolumn{7}{c}{ Means } \\
\hline WithNaCl & $1.21 \mathrm{a}$ & $127.5 \mathrm{a}$ & $1.32 \mathrm{a}$ & $56.73 \mathrm{a}$ & $84.71 \mathrm{a}$ & $85.64 \mathrm{a}$ \\
Without $\mathrm{NaCl}$ & $1.09 \mathrm{~b}$ & $107.6 \mathrm{~b}$ & $1.27 \mathrm{a}$ & $56.82 \mathrm{a}$ & $62.30 \mathrm{~b}$ & $75.63 \mathrm{~b}$ \\
\hline
\end{tabular}

${ }^{*}$ Significant and $5 \%$ probability; ns = not significant by the $\mathrm{F}$ test. Means followed by the same letter in the column do not differ at $5 \%$ probability by the Newman Keuls test.

The low Si percentage in the leaves and roots of Eucalyptus urocam plants was indicative that this species does not accumulate this nutrient, but it was possible to verify that the accumulation in roots and leaves was much bigger in plants irrigated with non-saline water. The lower percentage of sodium in the leaves and roots may be related to the beneficial effects of Si (Table 2). The presence of Si certainly reduced sodium absorption due to alterations in the stability of the plasmatic membrane and activation of detoxification mechanisms.

According to Ma et al. (2004) Si activates $\mathrm{H}^{+}$-ATPase of the root plasmatic membrane and helps reduce sodium absorption. The chloride concentration was $24 \%$ and $63 \%$ higher in the leaves and roots, respectively, of plants irrigated with saline water. These results indicate that Eucalyptus urocam plants have less chlorine absorption control compared to sodium. According to Feijão, Silva, Marques, Prisco e Gomes-Filho (2011) chlorine competes at the absorption sites with anions such as nitrate and can cause serious nutritional deficiency if it is absorbed in large quantities. The Table 3 show the partitioning of the previous table where the irrigation water salinity increased $\mathrm{Na}$ accumulation in the Eucalyptus urocam leaves but the sodium concentrations were lower than in leaves fertilized with Si.

Table 2. Analysis of variance and means tests for percentages of chlorine ( $\mathrm{Cl})$, silicon ( $\mathrm{Si}$ ) and sodium (Na) in the leaves and roots of Eucalyptus urocam plants fertilized with silicon and irrigated with saline water

\begin{tabular}{|c|c|c|c|c|c|c|c|}
\hline \multirow{3}{*}{ Source of variation } & \multirow{3}{*}{ GL } & \multicolumn{6}{|c|}{ Mean Squares } \\
\hline & & $\mathrm{Cl}$ leaf & $\mathrm{Cl}$ root & Si leaf & Si root & Na leaf & Na root \\
\hline & & \multicolumn{2}{|c|}{ 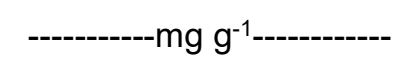 } & \multicolumn{4}{|c|}{ - } \\
\hline $\mathrm{Si}$ & 1 & $6.12^{\mathrm{ns}}$ & $38.58^{\text {ns }}$ & $0.0016^{\mathrm{ns}}$ & $0.0064^{*}$ & $180.09^{* *}$ & $684.59^{* *}$ \\
\hline $\mathrm{NaCl}$ & 1 & $114.79^{*}$ & $739.6^{*}$ & $0.0004^{*}$ & $0.001^{* *}$ & $3043.13^{* *}$ & $8169.66^{* *}$ \\
\hline $\mathrm{Si}^{*} \mathrm{NaCl}$ & 1 & $16.81^{\text {ns }}$ & $10^{-4 n s}$ & $0.0004^{*}$ & $0.0004^{\mathrm{ns}}$ & $30.49^{\text {ns }}$ & $461.48^{\text {ns }}$ \\
\hline Residue & 15 & 16.19 & 9.58 & 0.0004 & 0.0001 & 14.40 & 9.38 \\
\hline CV (\%) & & 24.82 & 24.34 & 15.60 & 15.70 & 11.28 & 7.36 \\
\hline Treatment 1 & & \multicolumn{6}{|c|}{ Means } \\
\hline With Si & & $15.72 a$ & $11.45 a$ & $0.03 a$ & $0.08 a$ & $30.91 b$ & $36.25 b$ \\
\hline Without Si & & $15.71 a$ & $13.98 a$ & $0.02 a$ & $0.05 b$ & $36.39 a$ & $46.93 a$ \\
\hline Treatment 2 & & \multicolumn{6}{|c|}{ Means } \\
\hline WithNaCl & & $13.84 b$ & $6.68 \mathrm{~b}$ & $0.20 \mathrm{a}$ & $0.60 a$ & $2.33 b$ & $2.31 \mathrm{~b}$ \\
\hline Without $\mathrm{NaCl}$ & & $18.22 a$ & $17.82 a$ & $0.03 b$ & $0.07 b$ & $4.49 a$ & $6.00 a$ \\
\hline
\end{tabular}

*Statistics as in Table 1.

Table 3. Means test for the variables: percentages of silicon $(\mathrm{Si})$ and sodium $(\mathrm{Na})$ in the leaves referent to the partitioning of the significant interactions between silicon-based fertilization and salinity in Eucalyptus urocamplants

\begin{tabular}{cccccc}
\hline & \multicolumn{2}{c}{ Si Leaf (\%) } & \multicolumn{2}{c}{ Na Leaf (\%) } \\
\cline { 2 - 3 } \cline { 5 - 6 } With $\mathrm{Si}$ & Without NaCl & With NaCl & & Without NaCl & With NaCl \\
\cline { 2 - 3 } \cline { 5 - 6 } Without $\mathrm{Si}$ & $0.02 \mathrm{aB}$ & $0.02 \mathrm{aB}$ & & $22.18 \mathrm{aB}$ & $50.31 \mathrm{bA}$ \\
& $0.02 \mathrm{aA}$ & $0.02 \mathrm{aA}$ & & $24.09 \mathrm{aB}$ & $69.76 \mathrm{aA}$ \\
\hline
\end{tabular}


Means followed by the same lowercase letter in the column and uppercase letter on the line do not differ at $5 \%$ probability by the Newman Keuls test.

The lack of statistical difference for the nutritional variables observed in Table 4 show that the salinity of the irrigation water did not cause severe nutritional disturbances. It is further pointed out that the potassium leaf concentration was $7 \%$ lower in plants under salinity. Sodium must have altered the integrity of the plasmatic membrane and increased its inflow in detriment to potassium, as reported by Taiz e Zeiger (2017).

Table 4. Analysis of variance and means test for the leaf concentrations of iron(Fe), phosphorus $(P)$, magnesium $(\mathrm{Mg})$, calcium $(\mathrm{Ca})$, potassium $(\mathrm{K})$ and zinc $(\mathrm{Zn})$ in the leaf tissue of Eucalyptus urocam plants fertilized with silicon and irrigated with saline water

\begin{tabular}{|c|c|c|c|c|c|c|c|}
\hline \multirow{3}{*}{ Source of Variation } & \multirow{3}{*}{ GL } & \multicolumn{6}{|c|}{ Mean Squares } \\
\hline & & $\mathrm{Fe}$ & $\mathbf{P}$ & Mg & $\mathrm{Ca}$ & $\mathbf{K}$ & $\mathrm{Zn}$ \\
\hline & & \multicolumn{6}{|c|}{ - } \\
\hline Si & 1 & $0.00007^{\mathrm{ns}}$ & $0.14^{\text {ns }}$ & $0.023^{\text {ns }}$ & $0.09^{\text {ns }}$ & $0.04^{\mathrm{ns}}$ & $33.18^{\text {ns }}$ \\
\hline $\mathrm{NaCl}$ & 1 & $0.12042^{\text {ns }}$ & $0.54^{\mathrm{ns}}$ & $0.36^{\mathrm{ns}}$ & $0.07^{\mathrm{ns}}$ & $13.20^{*}$ & $91.72^{\text {ns }}$ \\
\hline $\mathrm{Si}^{*} \mathrm{NaCl}$ & 1 & $0.00042^{\text {ns }}$ & $0.10^{\text {ns }}$ & $0.01^{\mathrm{ns}}$ & $2.26^{\mathrm{ns}}$ & $0.19^{\text {ns }}$ & $6.36^{\text {ns }}$ \\
\hline Residue & 15 & 0.07000 & 2.41 & 0.08 & 0.75 & 1.32 & 31.15 \\
\hline CV (\%) & & 11.41 & 11.76 & 14.35 & 8.85 & 5.94 & 11.01 \\
\hline Treatment 1 & & Means & & & & & \\
\hline With Si & & $2.32 a$ & $3.03 a$ & $2.06 a$ & $9.90 a$ & $1.93 a$ & $4.94 a$ \\
\hline Without Si & & $2.32 a$ & $2.88 a$ & $2.01 a$ & $9.78 a$ & $1.93 a$ & $5.18 a$ \\
\hline Treatment 2 & & Means & & & & & \\
\hline WithNaCl & & $2.25 a$ & $2.80 a$ & $2.17 a$ & $9.78 a$ & $2.00 a$ & $4.86 a$ \\
\hline WithoutNaCl & & $2.39 a$ & $3.10 a$ & $1.92 a$ & $9.90 a$ & $1.86 \mathrm{~b}$ & $5.26 a$ \\
\hline
\end{tabular}

*Statistics as in Table 1.

The principal component analysis (PCA) show that axis 1 explained $62 \%$ of the variation in the data and axis 2, 20\% (Figure 1). Silicon-based fertilization did not cause any type of grouping on the axles, but it was observed that the treatments with plants irrigated with non-saline water were concentrated positively on axis 2 . The direction of transpiration increase was indicative that the reduced concentration of salts in the irrigation water promoted bigger water loss in the form of vapor because of the bigger stomata conductance and consequently greater growth by increase in the number of leaves and specific leaf area.

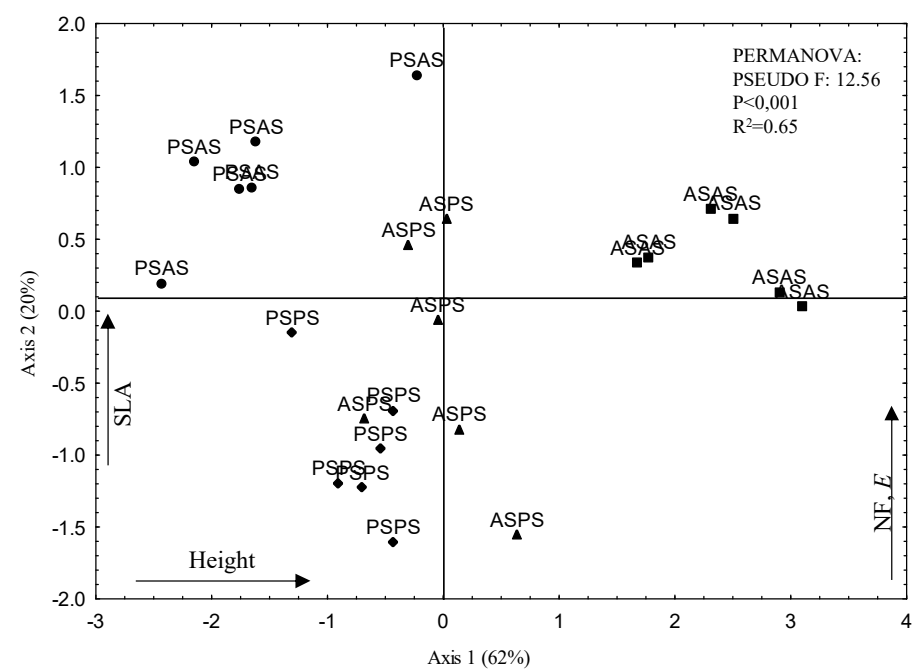

Figure 1. Ranking of the scores of the principal components analysis (PCA) for the variables analyzed. The arrow indicates the direction in which each variable with weighting above $80 \%$ increases in relation to the axle. The abbreviations mean: silicon presence and salt presence= PSPS, silicon absence and salt presence $=$ ASPS , silicon presence and salt absence $=$ PSAS, silicon absence and salt absence $=$ ASAS. SLA $=$ specific leaf area, $\mathrm{NF}=$ number of leaves and $E=$ transpiration . 
The slight reduction in growth, specifically in the biomass accumulation and small nutritional disturbance point to the possibility of cultivating Eucalyptus urocam plants irrigated with water with electrical conductivity less than $2.5 \mathrm{dS} \mathrm{m}^{-1}$ and thus occupying areas previously considered unsuitable for the development of the species because of the low availability of potable water. Using Si may be an important practice to reduce saline stress by reducing sodium absorption in Eucalyptus urocam plants, but studies with different doses are necessary for correct recommendation.

\section{Conclusions}

Silicon-based fertilization minimized sodium absorption in Eucalyptus urocam plants irrigated with saline water but did not influence chlorine entry in the plant. The vigorous vegetative growth, absence of nutritional deficiency and slight imbalance in potassium absorption indicated medium tolerance of Eucalyptus urocam plants to salinity with water with electrical conductivity equal to $2.5 \mathrm{dS} \mathrm{m}^{-1}$.

\section{References}

Amaro, C.L., Cunha, S.D., Grupioni, P.H.F., Sousa, P.V., D’abadia, K.L., Barros, I.B., Matos, F.S. (2017). Análise do crescimento de mudas de Eucalyptus sp. submetidas a diferentes doses de giberelina. Revista AgriEnvironmental Sciences, 3(1), 24-29. Recuperado de https://revista.unitins.br/index.php/agri-environmentalsciences/article/view/452

Associação dos Irrigantes do Estado de Goiás (IRRIGO). Brasil pode dobrar área irrigada até 2026 e se tornar um gigante mundial da produção de alimentos. Recuperado de https://www.irrigoias.com.br/single-post/Brasilpode-dobrar-area-irrigada-ate-2026-e-se-tornar-um-gigante-mundial-da-producao-de-alimentosDasgupta, $M$. G., Dharanishanthi, V., Agarwal, I., \& Krutovsky, K. $\quad$ V. (2015). Developmente of Genetic Markers in Eucalyptus Species by Target Enrichment and Exome Sequencin g. PloS ONE,10(1), 1-30. https://doi.org/10.1371/journal.pone.0116528Demattê, J. L. I., Pagiaro, C. M., Beltrame, J. A., \& Ribeiro, S. S. (2011). Uso de silicatos em cana-de-açúcar. Informações Agronômicas, 133, 7-12. Recuperado de http://www.ipni.net/publication/iabrasil.nsf/0/CF832453F89BC9D483257A8F005F59AE/\$FILE/Page7-12-133.pdf

Dos Anjos, R.A.R., Santos, L.C.S., Oliveira, D.B., Amaro, C.L., Rios, J.M., Rocha, G.T., Melo, B.S., Matos, F.S. (2017). Initial growth of Jatropha curcas plants subjected to drought stress and silicon (Si) fertilization. Australian Journal of Crop Science, 11(4), 479-484. https://doi.org/10.21475/ajcs.17.11.04.377

Du, H., Zeng, F., Peng, W., Wang, K., Zhang, H., Liu, L., Song, T. (2015). Carbon Storage in a Eucalyptus Plantation Chronosequence in Southern China. Forests, 6, 1763-1778. https://doi.org/ 10.3390/f6061763

Duarte, D M., Rocha, G.T., De Lima, F.B., Matos, F.S., Rodrigues, F. (2016). Responses of Paricá seedlings to water stress. Floresta, 46(3), 405 - 412. http://dx.doi.org/10.5380/rf.v46i3.39529

Empresa Brasileira de Pesquisa Agropecuária (EMBRAPA) (1997). Manual de Métodos de Análise de Solos (2ª ed.). Rio de Janeiro:EMBRAPA-CNPS.

Feijão, A.R., Silva, J.C.B.J., Marques, E.C., Prisco, J.T., Gomes-Filho, E. (2011). Efeito da nutrição de nitrato na tolerância de plantas de sorgo sudão à salinidade. Revista Ciência Agronômica, 42(3), 675-683. Recuperado de https://ccarevista.ufc.br/seer/index.php/ccarevista/article/view/1754/592

Freitas, I.A.S., Dos Santos, L.V.B., Da Silva, A.C.F., Da Silva, C.R., Da Silveira, P.S., Matos, F.S. (2017). Growth of Tectona grandis seedlings irrigated with saline water. Ciência Florestal, 27(3), 961-967. http://dx.doi.org/10.5902/1980509828667

Gama, J.S.N., Júnior, L.R.P., Pereira, F.J.S., Oliveira, E.L., Campos, D.A., Barros, A.C.S.A. (2016). Efeito da adubação silicatada na qualidade da fibra do algodoeiro. Magistra, 28(2), 244-253. Recuperado de https://magistraonline.ufrb.edu.br/index.php/magistra/article/view/50 
Hussein, M.M., Abou-Baker, N.H. (2014). Growth and Mineral Status of Moringa Plants as Affected by Silicate and Salicylic Acid under Salt Stress. International Journal of Plant \& Soil Science, 3(2),163-177. Recuperado de https://www.researchgate.net/publication/262182430_Growth_and_Mineral_Status_of_ Moringa_Plants_as_Affected_by_Silicate_and_Salicylic_Acid_undēr_SaltStress

Industria Brasileira de Árvores (IBÁ). Relatório 2017 IBÁ. Recuperado de http://iba.org/images/shared/Biblioteca/IBA_RelatorioAnual2017.pdf

Instituto Brasileiro de Geografia e Estatística (IBGE). Produção da Extração Vegetal e da Silvicultura - PEVS 2016. Recuperado de https://www.ibge.gov.br/estatisticas-novoportal/economicas/agricultura-e-pecuaria/9105producao-da-extracao-vegetal-e-da-silvicultura

Lopes, C.T., Lima, K.B., Klar, A.E. (2012). Desenvolvimento inicial de plantas de Eucalyptus platyphylla submetidas a níveis de salinidade. Irriga, 17(4), 494-500. https://doi.org/10.15809/irriga.2012v17n4p494

Lima, M.A., Castro, V.F., Vidal, J.B., Enéas-Filho, J. (2011). Aplicação de silício em milho e feijão-de-corda sob estresse salino. Revista Ciência Agronômica, 42(2), 398-403. https://doi.org/10.1590/S180666902011000200019

Ma, J.F., Mitani, N., Nagao, S., Konishi, S., Tamai, K., Iwashita, T., Yano, M. (2004). Characterization of the silicon uptake and molecular mapping of the silicon transporter gene in rice. Plant Physiology, 136(2), 32843289. https://doi.org/10.1104/pp.104.047365

Marafon, A.C., Endres, L. (2013). Silicon: fertilization and nutrition in higher plants. Amazionian Journal of Agricultural and Environmental Sciences, 56(4), 380-388. https://dx.doi.org/10.4322/rca.2013.057

Martins, C.C., Pereira, M.R.R., Lopes, M.T.G. (2013). Germination of eucalyptus seeds under water and salt stress. Bioscience Journal, 30(1), 318-329. Recuperado dehttp://hdl.handle.net/11449/117792

Matos, F.S., Silveira, P.S., Barretto, V.C.M., Freitas, I.A.S., Araujo, M.S., Calixto Junior, J.E.D., Rios, J.M. (2016). Growth of Khaya senegalensis plant under water deficit. African Journal of Agricultural Research,11(18), 1623-1628.https://doi.org/10.5897/AJAR2016.10920

Murphy, J., Riley, J.P. (1962). A modified single solution method for the determination of phosphate in natural waters. Analytica Chimica Acta, 27, 31-36. https://doi.org/10.1016/S0003-2670(00)88444-5

$\mathrm{R}$ Core Team, R: A language and environment for statistical computing. Vienna, Austria:R Foundation for Statistical Computing. Recuperado de http://www,R-project,org/

Ribeiro, A. C., Guimarães, P. T. G., \& Alvarez, V. H. (1999). Recomendações para uso de corretivos e fertilizantes em Minas Gerais ( $5^{\mathrm{a} e d}$.). Viçosa: CFSEMG

Santos, H.G., Jacomine, P.K.T., Anjos, L.H.C., Oliveira, V.A., Oliveira, J.B., Coelho, M.R., Lumbreras, J.F., Cunha, T.J.F. (2013). Sistema Brasileiro de Classificação de Solos (3ª ed.). Rio de Janeiro: Embrapa Solos

Shannon, M.C., Crieve, C.M., Francois, L.E. (1994). Whole Plant Response to Salinity. In: Wilkiman, R. E. (Ed.), Plant Environment Interactions (pp.199-244). New York: Marcel Dekker

Schweitzer, V.R. (2016). Origem do "lenho anormal de compressão" e efeitos sobre a qualidade da madeira de Pinus taeda da região serrana de Santa Catarina (Dissertação de Mestrado). Universidade Federal do Paraná, Paraná, PR, Brasil

Sokal, R.R., Rolf, F.J. (1995). Biometry (3ª ed.). New York: W. H. Freeman

Souza, B.R., Freitas, I.A.S., Lopes, V.A., Rosa, V.R., Matos, F.S. (2015). Growth of eucalyptus plants irrigated with saline water. African Journal of Agricultural, 10(10), 191-196. https://doi.org/10.5897/AJAR2014.9087

Taiz, L., Zeiger, E. (2017). Fisiologia vegetal (6ª ed.).Porto Alegre: ArtMed

Tedesco, M.J., Gianello, C., Bissani, C.A., Bohnen, H., Volkweiss, S.J. (1995). Análise de solo, plantas e outros materiais. Boletim Técnico de Solos, 2.ed,p. 174 
Wellburn, A.R. (1994). The spectral determination of chlorophylls a and b, as well as total carotenoids, using various solvents with spectrophotometers of different resolution. Journal of Plant Physiology, 144(3), 307-313. https://doi.org/10.1016/S0176-1617(11)81192-2

Yu, S., Zhang, Yi., Han, W., Feng, R., Hu, Y., Guo, J., Gong, H.(2016). Silicon Enhances Water Stress Tolerance by Improving Root Hydraulic Conductance in Solanum lycopersicum L. Frontiers in Plant Science, 22(7), 196210. https://doi.org/10.3389/fpls.2016.00196 